\title{
Japan's Measures on Export Control to the Republic of Korea: From the Perspective of International Law
}

\author{
Kotaro Shiojiri*
}

Japan has argued that its recently introduced export control measures toward the Republic of Korea (ROK) are consistent with relevant international guidelines. The ROK has rejected this view and claims that Japan's measures are inconsistent with World Trade Organization (WTO) law. If a WTO Panel is established to adjudicate this matter, the national security exception clause, specifically Article XXI of the General Agreement on Tariffs and Trade 1994 (GATT 1994), is likely to be invoked. Russia-Measures concerning Traffic in Transit is one of the few cases in which a WTO Panel has rendered a decision on this article. In general, the doctrine of precedents does not strictly apply; however, it hints that the Panel may require objective arguments to be provided despite the clause's "self-judging" nature. On its face, Japan appears to have a stronger case, but the Panel would nonetheless be required to make a difficult decision.

\section{Keywords}

Control, WTO, National Security Exception Cause, Article XXI of GATT 1994, Japan, Republic of Korea

* Ph.D. candidate at the University of Tokyo, Graduate School of Public Policy. LL.B./M.A. (Tokyo), LL.M. (Harvard). ORCID: https://orcid.org/0000-0002-4763-5279. The author would extend the deep gratitude to Professor Kazuhiro Nakatani for his valuable comments. The opinion in this paper is the view of the author and does not represent any views of entities including the University of Tokyo. The author may be contacted at: kotaroshiojiriuniversity@gmail. com/Address: 7-3-1 Hongo, Bunkyo-ku, Tokyo 113-8656. All the websites cited in this paper was last visited on October 12, 2019. 


\section{Introduction}

On July 1, 2019, the Japanese Ministry of Economy, Trade and Industry ("METI") announced an update of its licensing policies and procedures regarding the export and transfer of controlled items and their relevant technologies to the Republic of Korea ("ROK"). ${ }^{1}$ This announcement triggered international discussions not only on export control policies, but also on the broader state of the Japan-ROK relationship. Among other issues, whether Japan's new export control measures against the ROK amounts to a breach of its obligations under international law has been argued at various fora.

Multilateral regimes such as the Wassenaar Arrangement have historically provided common guidelines on export controls governing arms as well as dualuse goods and technologies. These guidelines are mostly non-binding and it is up to individual countries and regions to implement them through their respective domestic systems and operations. Japan has argued that its recently introduced export control measures toward the ROK are consistent with these international guidelines. The ROK has rejected this view and claims that Japan's measures are inconsistent with World Trade Organization ("WTO”) law. ${ }^{2}$

If a WTO Panel is established to adjudicate this matter, the national security exception clause, specifically Article XXI of the General Agreement on Tariffs and Trade 1994 ("GATT 1994”), is likely to be invoked. Russia-Measures concerning Traffic in Transit hints that the Panel may require objective arguments to be provided despite the "self-judging" nature of the clause. Japan's main arguments may include: (a) legal and administrative analysis showing the inadequacy of the ROK's export control system; (b) concrete data showing cases of illegal exports of covered strategic goods; and (c) evidence showing that the measures are within the bounds of accepted international practice. The ROK would likely utilize this process to promote the effectiveness of its export control not only to Japan but also to other countries and regions. On its face, Japan appears to have a stronger case, but the Panel would nonetheless be required to make a difficult decision.

This research provides an outline of the event and the author's analysis on the

1 METI, Update of METI's licensing policies and procedures on exports of controlled items to the Republic of Korea (July 1, 2019), available at https://www.meti.go.jp/english/press/2019/0701_001.html.

2 See, e.g., As Japan and South Korea clash at WTO over Trade, Rest of the World Reluctant to Get Involved, JAPAN TIMEs, July 25, 2019, available at https://www.japantimes.co.jp/news/2019/07/25/business/japan-south-korea-clashwto-trade-rest-world-reluctant-get-involved/\#.XUqQ1-j7Ryx. 
matter from the perspective of international law. This paper is composed of five parts including Introduction and Conclusion. Part II will provide an overview of international agreements on export controls. Part III will explain Japan's export control system and the recent update of Japan's measures. Part IV will analyze how a legal dispute over these measures might evolve in the context of the WTO's dispute settlement process. The main topic of this analysis is the national security exception clause including Article XXI of the GATT 1994, which leads to the Conclusion.

\section{Multilateral Export Control Regime ${ }^{3}$}

\section{A. Non-binding Agreements}

International agreements on export controls for arms and dual-use goods and technologies are implemented by individual countries and regions. Such controls, which are designed to promote international peace and security, are operated most effectively and efficiently when actors cooperate with each other. To this end, like-minded countries have formed several multilateral export control regimes ${ }^{4}$ including the Zangger Committee ("ZC"), the Nuclear Suppliers Group ("NSG"), the Australia Group ("AG"), ${ }^{7}$ the Missile Technology Control Regime ("MTCR"), and the Wassenaar Arrangement ("WA"). ${ }^{9}$ These regimes provide common, non-binding guidelines on export controls with regard to specific arms and dual-use goods and technologies for their participants.

Japan and the ROK are participants to all five regimes. This does not mean that both countries have the same export control systems and operations. Although there is a common set of guidelines, interpretation of these guidelines and the means through which they are operationalized vary by country and region. Participants

3 Kazuhiro Nakatani, Security Export Control and International Law [安全保障輸出管理と国際法], INTERNATIONAL SOCIETY AND SOFT LAW [国際社会とソフトロー], 113-35 (Yuhikaku Co., 2008). < available only in Japanese>

4 The focus of this paper is the international export control regime which regulate trades of weapons as opposed to weapons themselves. International agreements that directly regulate nuclear weapons, biological and chemical weapons include Nuclear Non-proliferation Treaty (NPT), Biological Weapons Convention (BWC), Chemical Weapons Convention (CWC).

5 See the official website of ZC, available at http://zanggercommittee.org.

6 See the official website of NSG, available at http://www.nuclearsuppliersgroup.org/en.

See the official website of AG, available at https://australiagroup.net/en.

8 See the official website MTCR, available at https://mtcr.info.

9 See the official website of WA, available at https://www.wassenaar.org. 
have the discretion to implement their own export controls through domestic measures that are legally binding. In the case of potential violation of these guidelines, a country claiming violation can accuse the suspected violating country through bilateral and multilateral diplomatic channels and, at most, the violating participant can be ousted from the regime if participants in said regime form a consensus to do so.

On April 28, 2004, acting under Chapter VII of the Charter of the United Nations, the United National Security Council Resolution ("UNSCR") $1540^{10}$ was adopted unanimously. It reads that "all States shall take and enforce effective measures to establish domestic controls to prevent the proliferation of nuclear, chemical, or biological weapons and their means of delivery, including by establishing appropriate controls over related materials." With this resolution, non-binding guidelines also became part of the UN architecture.

\section{B. Binding Agreements}

The Arms Trade Treaty ("ATT") came into force on December 24, 2014. ${ }^{11}$ As of the date of this article's publication, ATT has 104 State Parties, ${ }^{12}$ including Japan and the ROK. This treaty covers battle tank, armored combat vehicle, large-caliber artillery system, combat aircraft, attack helicopter, warship, missiles and missile launchers, small arms, and light weapons. ATT is a binding international agreement on regulations of the international trade in conventional arms and establishes international standards governing arms transfers. The level of rules and regulations of ATT are not yet as strict as the non-binding guidelines which are described above. ${ }^{13}$

At the 5th Conference of State Parties to ATT on August 28, 2019, the ROK delegation "expressed regret that Japan had taken export-restrictive measures in a unilateral and arbitrary manner for political purposes even when the ROK government has been faithfully implementing export control norms of the international community and rigorously controlling illegal transfers of conventional weapons to third countries." The delegation "called for an immediate withdrawal of such trade-restrictive measures and underlined the need to resolve the issue through consultations between the two countries."14

S.C. Res. 1540 (Apr. 28, 2004), U.N. Doc. S/RES/1540, available at https://undocs.org/S/RES/1540\%20(2004).

11 See the official website of ATT, available at https://thearmstradetreaty.org/\#.

12 Id. Canada became the 104th State Party on September 15, 2019, following its accession on June 19, 2019.

13 See Part II. A of this paper.

14 ROK Ministry of Foreign Affairs, ROK Points Out Inappropriateness of Japan's Measures to Impose Export Restrictions at the 5th Conference of State Parties to ATT, Press Release, Aug. 28, 2019, available at http://www.mofa. 
Against this claim, Japan points out that its measure "simply rectifies the operation of Japan's domestic export controls in response to circumstances such as limitations of the ROK's export control system and the operation thereof." 15 In other words, the dispute is framed here in terms of the effectiveness of the ROK's export control system. The ATT and other non-binding regimes on export control do not have a dispute settlement process. Therefore, if disputing participants cannot find solutions through bilateral consultations, they need to find another forum if they are to seek a clear settlement under international law. One of these fora is the WTO dispute settlement ("DS") process, as the operation of export control is traderestrictive in its nature.

If a case is brought to the WTO DS process, the complainant will point out the trade-restrictive nature of the measure taken. One of the arguments that the respondent can make is to argue that the measure taken is done in accordance with the common guidelines of the multilateral regimes. ${ }^{16}$ Should the dispute between Japan and the ROK follow this pattern, the functioning of Japan's export control system will be an important factor for the WTO to consider. ${ }^{17}$ Hence, in Part III, Japan's measures regarding export control are explained which is followed by a possible scenario of the WTO DS process.

\section{Japan's Export Controls}

\section{A. Overview of Architecture ${ }^{18}$}

The basic architecture of Japan's export control system and its operation is explained in a report submitted by the Government of Japan ("GoJ") to the Security Council Committee established pursuant to UNSCR 1540 on October 28, 2004. ${ }^{19}$ With regard

go.kr/eng/brd/m_5676/view.do?seq=320655\&srchFr=\&amp;srchTo=\&amp;srchWord=\&amp;srchTp=\&amp;multi itm_seq=0\&amp;itm_seq_1 $=0 \& a m p ; i t m \_s e q \_2=0 \& a m p ;$ company_cd $=\& a m p ;$ company_nm=.

15 METI, Regarding Today's Announcement by the ROK Government, News Release, Aug. 28, 2019, available at https://www.meti.go.jp/english/press/2019/0828_001.html.

16 To that extent, non-binding regimes have the legal meaning as sources of opposability to the participants of those regimes. See Nakatani, supra note 3.

17 See Part IV of this paper.

18 For details of METI's export control system, see METI, Export Control, available at https://www.meti.go.jp/policy/ anpo/englishpage.html.

19 See Note verbal dated 28 October 2004 from the Permanent Mission of Japan to the United Nations addressed to the Chairman of the Committee, U.N. Doc. S/AC.44/2004(02)/49, available at https://undocs.org/S/AC.44/2004/(02)/49. 
to its licensing system, Japan explains:

Based on the Foreign Exchange and Foreign Trade Law, permission is required to export 15 items of goods and technologies which are listed in the Attached list 1 of the Export Trade Control Order (Executive Order No.378 of 1949) $\left[{ }^{20}\right]$ and the Attached List of Foreign Exchange Order (Executive Order No.260 of 1980) [ ${ }^{21}$, respectively. The listed goods and technologies include those related to WMD [(weapons of mass destruction) $]^{22}$

The GoJ maintains:

To further enhance export controls with a view to strengthening the nonproliferation of weapons of mass destruction, Japan introduced the catchall controls $\left[{ }^{23}\right]$ in April 2002. A license must be obtained from the Minister for Economy, Trade and Industry for the export of virtually all goods and technologies (including those that are not listed), as long as the end-uses of the goods and technologies are related to weapons of mass destruction. ${ }^{24}$

METI applies specific licensing policies and procedures for implementing its export control on a country-by-country basis, taking into account how a specific country implements its export control. ${ }^{25}$ Relevant to the recent update by METI is the Appended Table III of the Export Control Order, ${ }^{26}$ the so-called "white countries list." Countries listed in this table have often been referred to as "white list countries" or "preferred trade partner list countries." If a country is listed in this table, exporters can utilize the General Bulk Export License for export and technology transfers to that country. Exporters can also utilize the Special General Bulk Export License. Compared to the General Bulk Export License, the Special General Bulk Export License is granted to exporters that meet higher standards. Individual export license

Export Trade Control Order, Cabinet Order No. 378 of Dec. 1, 1949, English translation (tentative), available at http:// www.japaneselawtranslation.go.jp/law/detail_download/?ff=14\&id=2150.

21 Foreign Exchange Order, Cabinet Order No. 260 of Oct. 11, 1980, English translation (tentative), available at http:// www.japaneselawtranslation.go.jp/law/detail/?id=3277\&vm=04\&re=02.

22 Supra note 19.

23 "Catch-all control" stands for an individual export license which is required for exports of non-listed items, both goods and technologies, in case where there are concerns that the items in question could have military end-uses or be applicable to WMD-related activities. See, e.g., METI, The Cabinet Approved Partial Amendment to the Export Trade Control Order, News Release, Aug. 2, 2019, available at https://www.meti.go.jp/english/press/2019/0802_001.html.

24 Supra note 19.

25 METI, supra note 1.

26 Export Trade Control Order, supra note 20. 
applications for items subject to the Special General Bulk Export License are accepted at the Regional Bureaus of Economy, Trade and Industry as well as Trade Offices of METI. ${ }^{27}$

Prior to August 2019, the 27 countries on Japan's “white countries list” were: Argentina, Australia, Austria, Belgium, Republic of Bulgaria, Canada, Czech Republic, Denmark, Finland, France, Germany, Greece, Hungary, Ireland, Italy, the ROK, Luxemburg, Netherlands, New Zealand, Norway, Poland, Portugal, Spain, Sweden, Switzerland, the UK, and the US. ${ }^{28}$ These countries were selected from among the countries that are participants to all five multilateral export control regimes, but with the condition that Japan considers those countries to be implementing effective export controls through their domestic systems and operations including the introduction of catch-all controls. The ROK was added to this list in 2004, but, as described below, Japan changed its practice on August 28, 2019. ${ }^{29}$

\section{B. Recent Update of Japan's Measures ${ }^{30}$}

On July 1, 2019, Japanese METI announced the change in "its implementation practices such as licensing policies and procedures for export or transfer of controlled items and their relevant technologies to the ROK." The announcement was made as the result of "careful consideration among the relevant ministries in Japan" through which the GoJ determined that "the Japan-ROK relationship of trust including in the field of export control and regulation has been significantly undermined."31

Two changes were made following this announcement. ${ }^{32}$ First, the Appended Table III of the Export Control Order, ${ }^{33}$ or the "white countries list," was changed into a list of countries divided into four categories. According to the announcement, "the status of countries and regions that were not classified as "white list countries" in terms of the application of Japanese export control statutes, including the

27 METI, supra note 23.

28 METI, Export Control: Transshipment and Regulation and Broker Trade Regulation, available at https://www. meti.go.jp/policy/anpo/securityexportcontrol3.html.

29 See Part III. B of this paper.

30 Yoshiaki Takayama, Japan Institute of International Affairs (JIIA)'s Strategic Comment No. 11: On the Review of Export Control toward the ROK [国問研戦略コメント（No.11）韓国向け輸出管理の運用見直しについて]<available only in Japanese>, JIIA [日本国際問題研究所], July 12, 2019, available at http://www2.jiia.or.jp/RESR/column_page. php?id=362.

31 METI, supra note 1.

32 METI, On the Notice Partially Revising the Operation of Export Trade Control Order [「輸出貿易管理令の運用について」 等の一部を改正する通達について] <available only in Japanese>, available at https://www.meti.go.jp/policy/anpo/law_ document/tutatu/190701_gaiyo.pdf.

33 Export Trade Control Order, supra note 20. 
applicability of bulk licenses, varied depending on their membership status in the various international export control regimes and other conditions. Therefore, METI decided to re-categorize countries and regions reflecting their actual statuses within Japanese statutes into four categories, namely: Group A) Countries and regions listed in the Appended Table III of the Export Trade Control Order; Group B) Countries and regions participating in international export control regimes and satisfying certain conditions (excluding those in Group A); Group C) Countries and regions not falling within any of Groups A, B or D; and Group D) Countries and regions listed in the Appended Table III-2 or Appended Table IV of the Export Trade Control Order. ${ }^{34}$ This change came into effect on August 28, 2019.

Second, "as METI has recently found that certain sensitive items have been exported to the ROK with inadequate management by companies," the Ministry decided to "apply more stringent procedures over certain items and their relevant technologies. ${ }^{35}$ Those items include Fluorinated Polyimide, Resist, and Hydrogen Fluoride. From July 4, 2019, exporters are required "to obtain an individual export license for export of these three items and their relevant technologies, which may include technology transferred with exports of manufacturing equipment" to the $\mathrm{ROK}^{36}$

In effect, the ROK was removed from the "white countries list" (the ROK was reclassified under Group B) ${ }^{37}$ and more stringent procedures are being implemented to exporters of specific items and relevant technologies to the ROK. METI has stated that this updated licensing policies and procedures on the export and transfer of controlled items and their relevant technologies to the ROK was introduced "in order to ensure appropriate implementation of export control and regulation. ${ }^{38}$ How these measures will be evaluated under the WTO law is our next topic. ${ }^{39}$

36 Id

37 Public opinion on this removal began on July 1, 2019. See Ministry of Internal Affairs and Communications of Japan e-Gov, Summary of Public Comments No. 595119079 [輸出貿易管理令の一部を改正する政令案の意見募集の結果 について], <available only in Japanese>, available at https://search.e-gov.go.jp/servlet/Public?CLASSNAME=PCMM STDETAIL\&id=595119079\&Mode $=2$.

38 METI, supra note 27.

39 See Part IV of this paper. 


\section{Evaluation under the WTO Law}

Under the WTO law, member countries are required to follow certain rules including general elimination of quantitative restrictions. ${ }^{40}$ Paragraph 1 of Article XI of the GATT 1994 read:

No prohibitions or restrictions other than duties, taxes or other charges, whether made effective through quotas, import or export licences or other measures, shall be instituted or maintained by any contracting party on the importation of any product of the territory of any other contracting party or on the exportation or sale for export of any product destined for the territory of any other contracting party. ${ }^{41}$

Most-favored-nation ("MFN") treatment is one of the core obligations under the WTO law. Article I of the GATT 1994 reads: "Any advantage, favour, privilege or immunity granted by any contracting party to any product originating in or destined for any other country shall be accorded immediately and unconditionally to the like product originating in or destined for the territories of all other contracting parties."42

As a principle, the WTO member countries are bound by these rules, but there are general exceptions that can be invoked. Article XXI of the GATT 1994, ${ }^{43}$ the so-called "national security exception clause," invoke if the ROK is to file an official complaint under the WTO law on this matter.

40 The WTO law that governs the field of trade in services is the General Agreement on Trade in Services (GATS). While the evaluation under the GATS is necessary to assess restrictions on transfers of technologies, the focus of this paper is the GATT 1994 because of limited space of paper. Analysis of the GATS will be similar to the one of the GATT as both follow similar logics.

41 WTO, Analytical Index of the GATT, art. XI, at 313-54, available at https://www.wto.org/english/res_e/publications e/ai17_e/gatt1994_art11_gatt47.pdf.

42 Id. art. I, at 23-61.

43 Id. art. XXI, at 598-610. Article XXI of the GATT 1994 reads as follows:

Nothing in this Agreement shall be construed

(a) to require any contracting party to furnish any information the disclosure of which it considers contrary to its essential security interests; or

(b) to prevent any contracting party from taking any action which it considers necessary for the protection of its essential security interests

(i) relating to fissionable materials or the materials from which they are derived;

(ii) relating to the traffic in arms, ammunition and implements of war and to such traffic in other goods and materials as is carried on directly or indirectly for the purpose of supplying a military establishment;

(iii) taken in time of war or other emergency in international relations; or

(c) to prevent any contracting party from taking any action in pursuance of its obligations under the United Nations Charter for the maintenance of international peace and security.

44 For the national security exception under GATS, see GATS art. XIV. 
Under the WTO DS process, after formal consultations, the Panel will be held to hear the case and will circulate its report. If there is an objection to the Panel report, the Appellate Body will be convened to render a final verdict. ${ }^{45}$ In light of the nature of the case, whether recent measures by METI fall within the national security exception clause will be at the center of the Panel's debate.

\section{A. National Security Exception Clause}

Article XXI (b) of the GATT 1994 is one of the clauses that Japan could invoke in the WTO DS process. ${ }^{46}$ There have been only few cases in which the WTO Panel made its decision on this article. One of them is the Panel report on Russia-Measures concerning Traffic in Transit (2019) (DS512) circulated on April 5, 2019, and adopted on April 26, 2019. ${ }^{47}$ Whether the Panel has jurisdiction to review Russia's invocation of Article XXI (b) (iii) of the GATT 1994 and to what extent can the Panel make its judgement on the case given the "self-judging" nature of the provision were discussed. In general, the doctrine of precedents does not strictly apply to the WTO DS process, but it does give clues for future cases. ${ }^{48}$

In Russia-Measures concerning Traffic in Transit (2019), Russia claimed that its invocation of Article XXI (b) is outside of the Panel's jurisdiction because the chapeau of Article XXI (b) reads "to prevent any contracting party from taking any action which it considers necessary for the protection of its essential security interests." this argument, the Panel responded that it has jurisdiction over the matter "given the absence in the DSU [dispute settlement understanding] of any special or additional rules of procedure applying to disputes involving Article XXI of the GATT 1994."50 Regarding the chapeau, the Panel points out:

The ordinary meaning of Article XXI(b)(iii), in its context and in light of the object

45 WTO, Dispute Settlement System Training Module: Chapter 6 The Process - Stages in a Typical WTO Dispute Settlement Case, available at https://www.wto.org/english/tratop_e/dispu_e/disp_settlement_cbt_e/c6s1p1_e.htm.

46 Others that might be invoked include Article XXI (c) of the GATT 1994. This would likely be invoked if Japan were to characterize its measures as domestic measures to maintain Japan's conformity to UNSCR 1540 under Chapter VII of the United Nations Charter.

47 Panel Report, Russia - Measures concerning Traffic in Transit, WTO Doc. WT/DS512/R (adopted Apr. 29, 2019) [hereinafter Russia Panel Report], available at https:/www.wto.org/english/tratop_e/dispu_e/512r_e.pdf.

48 Tsuyoshi Kawase, Special Report: Panel Report of Russia -Measures Concerning Traffic in Transit [ロシア·貨物通貨 事件パネル報告書 一米国·232条紛争の行方とWTO体制への影響] < available only in Japanese>, Research Institute of Economy, Trade and Industry, Apr. 9, 2019, available at https://www.rieti.go.jp/jp/special/special_report/104.html.

49 Russia Panel Report, supra note 47, 97.57.

50 Id. ๆๆ 7.56 \& 7.104. See also Certain Iranian Assets (Iran v. U.S.), Judgment, 2019 I.C.J. Rep. ๆๆ 38-47 (Feb. 13), available at https://www.icj-cij.org/files/case-related/164/164-20190213-JUD-01-00-EN.pdf. 
and purpose of the GATT 1994 and the WTO Agreement more generally, is that the adjectival clause 'which it considers' in the chapeau of Article XXI(b) does not qualify the determination of the circumstances in subparagraph (iii). Rather, for action to fall within the scope of Article XXI(b), it must objectively be found to meet the requirements in one of the enumerated subparagraphs of that provision. ${ }^{51}$

The Panel further argues:

[i]t would be entirely contrary to the security and predictability of the multilateral trading system established by the GATT 1994 and the WTO Agreements, including the concessions that allow for departures from obligations in specific circumstances, to interpret Article XXI as an outright potestative condition, subjecting the existence of a Member's GATT and WTO obligations to a mere expression of the unilateral will of that Member. ${ }^{52}$

The negotiation history of this article shows that:

The 'balance' that was struck by the security exceptions was that Members would have 'some latitude' to determine what their essential security interests are, and the necessity of action to protect those interests, while potential abuse of the exceptions would be curtailed by limiting the circumstances in which the exceptions could be invoked to those specified in the subparagraphs of Article $\mathrm{XXI}(\mathrm{b}){ }^{53}$

Then, the Panel argues:

[ $t$ ]he connection between the action and the materials or the traffic described in subparagraphs (i) and (ii) [of Article XXI (b)] is specified by the phrase 'relating to'. The phrase 'relating to', as used in Article XX(g) of the GATT 1994, has been interpreted by the Appellate Body to require a 'close and genuine relationship of ends and means' between the measure and the objective of the Member adopting the measure. $\left[{ }^{54}\right]$ This is an objective relationship between the ends and the means, subject to objective determination. ${ }^{55}$

51 Russia Panel Report, supra note 47, 97.82.

52 Id. $₫ 7.79$.

53 Id. $ๆ 7.89$.

54 Appellate Body Report, European Communities - Measures Prohibiting the Importation and Marketing of Seal Products, WTO Doc. WT/DS400/AB/R \& WT/DS401/AB/R (adopted May 22, 2014), available at http://www. worldtradelaw.net/document.php?id=reports/wtoab/ec-sealproducts(ab).pdf.

55 Russia Panel Report, supra note 47, ๆ 7.69. 
Regarding subparagraph (iii) of Article XXI (b) of the GATT 1994, "[t]he Panel recalls that the obligation of good faith is a general principle of law and a principle of general international law which underlies all treaties, as codified in Article 31(1) ("[a] treaty shall be interpreted in good faith ...”) and Article 26 ('[e]very treaty ... must be performed [by the parties] in good faith') of the Vienna Convention [on the Law of Treaties]." "Thus, as concerns the application of Article XXI(b)(iii), this obligation is crystallized in demanding that the measures at issue meet a minimum requirement of plausibility in relation to the proffered essential security interests." ${ }^{, 57}$

Export control of security sensitive items is a typical case which can fall under subparagraphs (i) and (ii) of Article XXI (b) of the GATT 1994. It is up to the discretion of member countries to 'consider' what is "necessary for protection of [their] essential security interests." Having said that, the Panel could require a "close and genuine relationship of ends and means" between the measure and the objective of the Member adopting the measure. Whether measures that were recently announced by Japanese METI adequately respond to this requirement is the topic of debate.

\section{B. Issues to be Discussed}

If the ROK is to seek settlement under the WTO system, ${ }^{58}$ the first step will be to request formal consultations with Japan claiming that METI's recent measures appear to be inconsistent with Article I and Article XI of the GATT 1994, among others. If the consultations are not successful, the ROK can request the establishment of a Panel. If a Panel is to be established, Japan is likely to invoke Article XXI (b) of the GATT 1994 as its response to the claim. ${ }^{59}$ The Panel will hear arguments from both sides on whether Japan acted within the range allowed under the national security exception clause. ${ }^{60}$

The ROK is likely to claim that the Panel should set strict guidelines for the case,

$56 \quad$ Id. 97.132.

57 Id. $\uparrow 7.138$.

58 On September 18, 2019, the Ministry of Trade, Industry and Energy of the ROK strengthened its export controls for Japan and moved Japan to a new export control category. Some argue that this is ROK's retaliation measure against Japan's measures. However, unilateral retaliations violate Article XXIII of the Understanding on Rules and Procedures Governing the Settlement of Disputes (DSU) and the ROK is not framing this measure as such. See, e.g., METI, Statement by Minister Sugawara on the Korean Government's Strengthening of Export Controls for Japan, Sept. 18, 2019, available at https://www.meti.go.jp/english/speeches/ministers_statements/2019/20190918_01.html.

59 Article XXI (c) of the GATT 1994 could be invoked as well. See supra note 46.

60 If Japan is to officially claim that a Panel should be established regarding the ROK 'retaliation' measure, whether the ROK acted within the range allowed under the national security exception will be the center of the dispute and the sides of the argument in the following will flip accordingly. See supra note 58. 
for example, requiring Japan to prove that there are no other less restrictive measures available. On the other hand, Japan is likely to argue that the guidelines should be less strict and that it is enough if Japan is to pass the 'necessity' test so that member countries' discretions on domestic security policy can be secured. There are no precedents on this matter, but the level of burden of proof is likely to be stricter than the one for Article XXI (b)(iii) of the GATT 1994. As described above, the Panel may set the guideline as whether there is a "close and genuine relationship of ends and means." ${ }^{, 1}$

On which side the burden of proof falls and to what extent each side needs to provide evidence are not clear. The $\mathrm{ROK}$, as a complainant, needs to prove that the Japanese measures are inconsistent with the WTO law. Japan, as a respondent, needs to support its measures with objective arguments. Japan's main arguments may include: (a) legal and administrative analysis showing the inadequacy of the ROK's export control system; (b) concrete data showing cases of illegal exports of strategic goods; and (c) evidence showing that the measures are within the practice admitted internationally.

Regarding (a), one of Japan's argument could be that the ROK's export control is not sufficient compared to the guidelines provided by WA and other multilateral regimes and, therefore, the recent measures taken by Japanese METI are necessary as a complement. ${ }^{62}$ The Korean statutes related to export control include the Foreign Trade Act, the Public Notice on Trade of Strategic Items, and the Special Measures for Restrictions on Trade for the Maintenance of International Peace and Security. ${ }^{63}$ Japan can argue that these statutes do not provide sufficient legal architecture to cover the wide range of items that are used for development of conventional weapons as they only cover WMDs and missile development-related items. ${ }^{64}$ In addition to the question on legal framework, whether a sufficient number of experts are on duty is also a point at issue which needs clarification. ${ }^{65}$

Regarding (b), Japan will benefit from any data showing illegal activities being overlooked by the ROK authorities. Media coverage says that "a total of 156 incidents of illegal exports of strategic goods were detected by the South Korean authorities

61 See Part IV(A) of this paper.

62 METI, Japan's Position on the Press Conference by MOTIE of the ROK on July 24th, News Release, July 24, 2019, available at https://www.meti.go.jp/english/press/2019/0724_001.html.

63 Foreign Trade Act, Act No. 13838, Jan. 27, 2016, available at https://elaw.klri.re.kr/eng_service/lawView.do?hseq $=37529$ \&lang $=$ ENG.

64 METI, supra note 62.

65 Clarification on legal framework and operation could have been made through bilateral consultations among experts, but such consultation has not taken place since June 2016. See supra note 62. 
between 2015 and March 2019" and two-thirds were related to weapons of mass destruction, according to a list obtained by an opposition lawmaker of the ROK. ${ }^{66}$ The GoJ has not released specific information on concrete cases since such a disclosure could include private sector information that could harm the businesses involved. ${ }^{67}$ If objective data can show that the number of cases of potential security threat has increased recently, the GOJ would have a stronger argument in terms of why it decided to opt for the recent measures.

Regarding (c), Japan could point out that the exclusion of the ROK from the white countries list is not a unique practice, but is actually a common practice of other countries and consistent with WA and other multilateral regimes on export control. For example, Australia ${ }^{68}$ and the European Union $^{69}$ each maintain white countries lists. Neither list includes the ROK. ${ }^{70}$ In addition, delisting from the white countries list does not mean that all exports are banned. Special General Bulk Export License is available for exporters and there are already cases in which specific exports to the ROK have been approved. ${ }^{71}$ Japan has a strong case if it can show that its measures are not unique but rather similar to or even less restrictive than the measures taken by other countries and are within the boundaries of internationally admitted guidelines.

The ROK needs, on the contrary, to make its case that the Korean export control is effective, while the recent Japanese measures are not consistent with the international standards. One of the strong points that the ROK can make is the fact that Japan allowed the ROK to be whitelisted in 2004. If so, why is it being denied that status after 15 years? Arbitrary and unilateral measures unrelated to the end of traderestriction are to be condemned. Against this claim, Japan may respond with the

66 Center for Strategic and International Studies (CSIS), RESOLVED: Japan has more to gain than to lose from its export controls on South Korea, 2:8 DEBATING JAPAN, Sept. 24, 2019, available at https://www.csis.org/analysis/resolved-japanhas-more-gain-lose-its-export-controls-south-korea. See also Yatanabe Yasuhiro, Leaks of strategic goods from South Korea? Acquired a list of "illegal export" of South Korea which is angry about the lift of favorable measures - Exports are surprised [...] illegal exports of strategic goods amounts to 156 incidents over four years [韓国から戦略物資ダダ 洩饥? 優遇措置撤廃で怒る韓国の「不正輸出」リスト入手-専門家驚愕…戦略物資の不正輸出は 4年間で 156 件も], Fuл TV, July 10, 2019, available at https://www.fnn.jp/posts/00047178HDK < available only in Japanese>.

67 METI, Interview of METI Minister Seko [世耕経済産業大臣の閣議後記者会見の概要] <available only in Japanese>, July 16, 2019, available at https://www.meti.go.jp/speeches/kaiken/2019/20190716001.html.

68 Department of Defence of Australia, Defence Export Controls, Export Controls Legislation, available at http://www. defence.gov.au/ExportControls/Legislation.asp.

69 European Commission, Dual-use Trade Controls, available at https://ec.europa.eu/trade/import-and-export-rules/ export-from-eu/dual-use-controls.

70 On the other hand, both lists include Japan as a white country.

71 See, e.g., Japan approves first export of hydrogen fluoride to South Korea since controls tightened, JAPAN TIMES, Aug. 30, 2019, available at https://www.japantimes.co.jp/news/2019/08/30/business/japan-exports-hydrogen-fluoride-southkorea/\#.XW8mPCj7Ryw. 
administrative history of the decision in 2004. The reason for the whitelisting may be that, whereas the legal and administrative system of the ROK were not sufficient, Japan made a political decision to 'trust' Korean export control ability to be sufficient and effective based on the political commitment and objective data provided by the ROK. If so, Japan may argue that those commitment and data, which were the condition of the 'trust,' have been removed. ${ }^{72}$

All in all, Japan seems to have a stronger case as described above. Japan and the ROK need to articulate their claims in a matter that is seen to be both objective and persuasive. Japan's main arguments will likely focus on objective reasons why the measures had to be taken given the current status of ROK export controls. The ROK, on the other hand, can utilize this process in order to promote the effectiveness of its export control not only to Japan but also to other countries and regions. They also need to be mindful of other cases in which they may be involved in the future. ${ }^{73}$ If other countries and regions are to join the WTO DS process as third countries, how they will support either side of the argument needs to be observed as well. How Australia, the European Union, Russia, the US and other members would react to this case will be of great interest. ${ }^{74}$ In any case, the Panel will be put in a rather difficult position as this case can be the first case to decide on subparagraphs (i) and (ii) of Article XXI (b) of GATT 1994.

\section{Conclusion: Way Forward}

At the general council meeting of the WTO on July 23-24, 2019, Japan and the ROK exchanged their views to which the Chair said that she "hoped that a bilateral, amicable solution could be found."75 To achieve such a solution, the likely first step required is for consultation among experts in order to clarify the effectiveness of the

72 The argument that the bilateral relationship of 'trust' in general has deteriorated, especially because of the issue of history, is irrelevant if it has nothing to do with the 'trust' on effective export control by the ROK.

73 Japan or ROK can either be the one invoking Article XXI of the GATT 1994 or the one being invoked. Therefore, claiming strongly for one side may harm its future position when it has to protect itself from the opposite side.

74 The ROK may point out that some States including Canada are whitelisted by Japan but their export control are not as effective as the one of the ROK. See, e.g., ROK Ministry of Trade, Industry and Energy, Statement to Media by Minister Sung on MOTIE's letter sent to Japan's METI, July 24, 2019, available at http://english.motie.go.kr/en/pc/ pressreleases/bbs/bbsView.do?bbs_seq_n=724\&bbs_cd_n=2\&currentPage $=1 \&$ search_key_n $=\&$ search_val_v $=\&$ cate $\mathrm{n}=$. If other countries' scheme is to be discussed in the case, those countries may join the case as third parties.

75 WTO, General Council, Summary of General Council meeting of 23-24 July 2019, July 23 \& 24, 2019, available at https://www.wto.org/english/news_e/news19_e/sum_gc_jul19_e.htm. 


\section{ROK's export controls. ${ }^{76}$}

If a Panel is established regarding this matter, it will be the first-ever case to test if a country's export control falls under the scope of national security exception clause of the WTO law. Japan seems to have a stronger case, but some argue that the establishment of such a Panel itself will be a challenge to the stability of the WTO law. ${ }^{77}$ While the art of ambiguity of the national security exception clause has helped to maintain the balance between member country's latitude on national security policy and the fight against potential abuse of the general exceptions, asking for clarity may shake this balance. Together with cases related to measures taken under Section 232 of the US Trade Expansion Act of 1962 (19 U.S.C. \$1862) ${ }^{78}$ among others, ${ }^{79}$ this case may contribute to the opening of Pandora's box with regard to international economic law. ${ }^{80}$ As such, we may be witnessing the start of the era of instability of international economic law.

76 On September 11, 2019, the ROK requested consultations with Japan regarding this matter. The consultation process started and the case (DS590) is named "Japan-Measures Related to the Exportation of Products and Technology to Korea." See WTO, DS590: Japan - Measures Related to the Exportation of Products and Technology to Korea, available at https://www.wto.org/english/tratop_e/dispu_e/cases_e/ds590_e.htm. See also supra notes 58 \& 60 .

77 Tsuyoshi Kawase, The Government of Japan should reconsider its export control against ROK - if disputed at the WTO, it will bring bigger risk [日本政府は韓国の輸出規制を再考すべきだ一WT0で争えば、より大きなリスクを招く] <available only in Japanese>, Toyokeizai Online, July 13, 2019, available at https://toyokeizai.net/articles/-/291562.

78 Related to the US action under US Trade Expansion Act of 1962 (19 U.S.C. §1862), United States - Certain Measures on Steel and Aluminum Products (DS544, DS547, DS548, DS550, DS551, DS552, DS554, DS556, DS564), which are being brought by Canada, China, EU, India, Mexico, Norway, Russia, Switzerland and Turkey against the US, are under process.

79 Other cases related to national security exception clause include United Arab Emirates - Measures relating to Trade in Goods and Services, and Trade-Related Aspects of Intellectual Property Rights (WT/DS526, UAE v. Qatar), BahrainMeasures relating to Trade in Goods and Services, and Trade-Related Aspects of Intellectual Property Rights (WT/DS 527, Bahrain v. Qatar), Saudi Arabia-Measures relating to Trade in Goods and Services, and Trade-Related Aspects of Intellectual Property Rights (WT/DS528, Saudi Arabia v. Qatar), Saudi Arabia-Measures concerning the Protection of Intellectual Property Rights (WT/DS567, Saudi Arabia v. Qatar), Qatar-Certain Measures concerning Goods from the United Arab Emirates (WT/DS576, Qatar v. UAE).

80 See, e.g., CSPAN, Deputy U.S. Trade Representative on WTO, Nov. 19, 2018, available at https://archive.org/details/ CSPAN3_20181119_140800_Deputy_U.S._Trade_Representative_on_World_Trade_Organization/start $/ 2400 /$ end $/ 2460$. 